\title{
RELIABILITY ANALYSIS OF FIRE SUPPRESSION SYSTEMS
}

\author{
UDC 519.873:614.84
}

\section{Dejan Ristić ${ }^{1}$, Milan Blagojević ${ }^{1}$, Nermin Haznadarević ${ }^{2}$, Milena Simić ${ }^{3}$}

\author{
${ }^{1}$ University of Niš, Faculty of Occupational Safety, Niš, Serbia \\ ${ }^{2}$ CIZ-Testing and Protection Center doo, Mostar, Bosnia and Hercegovina \\ ${ }^{3}$ Clinical Center Niš, Serbia
}

\begin{abstract}
The methods of fault tree and event tree are well-known methods for reliability analysis of technical systems. However, these methods are rarely applied in fire protection systems including fire alarm systems and fire extinguishing systems.

The aim of this paper is to use the hypothetical values of event probability, obtained through qualitative fault tree analysis, in order to obtain results that would indicate which individual events cause sprinkler system failure and which events are the most significant for, or contribute the most to, sprinkler system failure.
\end{abstract}

Key words: reliability, safety, fault tree analysis, fire protection systems, fire suppression system, standards

\section{INTRODUCTION}

A fire protection system, often referred to as a fire suppression system or a passive fire protection system, is a combination of materials and methods developed to prevent the spread of fire and to stop fire from causing irreparable damage to a building. [1]

Commercial premises are more likely to include comprehensive structural protection, and also the majority of passive fire protection methods. Domestic residences may include fireproof doors and some structural protection, but for the most part will only implement aspects of passive fire protection methods. The single most effective protection against fire is the fire sprinkler - in the home or business.

Sprinkler devices are fixed systems intended for automatic fire suppression using water and they allow maximum suppression efficiency and dependability. Efficient suppression is possible only if the installation is under constant and adequate pressure. Sprinklers are the oldest fixed fire protection systems. The first sprinkler device was patented in the United States in the second half of the 19th century. [4]

Received September 10, 2019 / Accepted September 16, 2019

Corresponding author: Dejan Ristić

Faculty of Occupational Safety. Čarnojevića 10a, 18000 Niš, Serbia

E-mail: dejan.ristic@znrfak.ni.ac.rs 
A sprinkler device is a fixed automatic system for fire suppression by means of spraying water. It is employed wherever water can be used as an efficient fire suppressant, especially in technological processes that require rapid intervention and carry high fire loading. [4]

Sprinkler devices are widely used in various industry branches, such as food manufacturing, chemical plants, sawmills, plastic processing, rubber manufacturing, paint and varnish manufacturing, battery manufacturing, tobacco production, pharmaceutical production, textile manufacturing, film archives, concert halls, department stores, cinemas, airplane hangars, as well as in all types of flammable material storage, where water is the most suitable fire suppressant.

\section{Methodology of FAUlt TREe CONSTRUCTION}

There are numerous methods for system reliability analysis, for instance, the reduction method and fault tree analysis. One of the most important methods for determining the reliability of complex networks is based on minimal path sets and minimal path sets [3].

A fault tree is constructed with the aim to model system conditions that can lead to an undesired event. This requires a system description. Fault trees are constructed using logic circuits "AND" and "OR" gate and standardized event and transfer symbols. [6]

Reliability network is widely used to determine the reliability of fire detection and alarm systems as well as fire suppression systems.

Qualitative analysis is the determination of minimal cut sets and minimal path sets. Minimal cut sets and minimal path sets represent two equivalent sources of information on the state of the system.

Minimal cut sets are those sets of events that are necessary for the occurrence of the top event. A cut is minimal when it does not contain any other cuts itself. [2]

A minimal path set is the smallest set of events, which must not occur if the top event is to be avoided, i.e. minimal path sets are the smallest sets of events, on which reliable functioning of the system (absence of the top event) is dependent. A path is minimal when it does not contain any other paths itself.

Initial derivation can be non-minimal or minimal so that each cut set containing a minimal cut set is not minimal.

Based on the created minimal cut set, it is possible to create an equivalent fault tree.

Cut sets can be used to establish the vulnerability to shared causes and for qualitative evaluation of the importance of minimal cut sets and events.

\section{Qualitative FAult TREE ANALYSIS OF FIRE SuPPRESSION SYSTEM}

A fire detection and alarm system comprises the following components: a monitoring and control device; alarm signaling elements; manual and automatic alarms; and auxiliary devices. The qualitative fault tree analysis for a fire detection and alarm system is performed by means of minimal cut sets and minimal path sets.

To conduct the qualitative fault tree analysis, we observed a system installed in a production hall. "The fire suppression system failed to activate" is the top event (T), which is the result of event A (no water supply), event B (no water distribution), event C (panel failure), and sprinkler failure. Event A results from event D (backup water supply 
failure) and event $\mathrm{E}$ (primary water supply failure), which is a consequence of water supply failure and isolated water supply. Event $\mathrm{C}$ results from event $\mathrm{F}$ (power supply failure), which is caused by the main power supply and backup power supply failure, and panel software and hardware failure. Event D results from tank failure, isolated water supply, and event $\mathrm{G}$ (diesel tank failure). Event $\mathrm{G}$ occurs due to hardware failure or due to event $\mathrm{F}$ (power supply failure), which in turn is due to main and backup power supply failure.

Figure 1 shows the fault tree of a fire suppression system, in which each event is represented by a number or a letter, depending on whether they are basic or combination events.

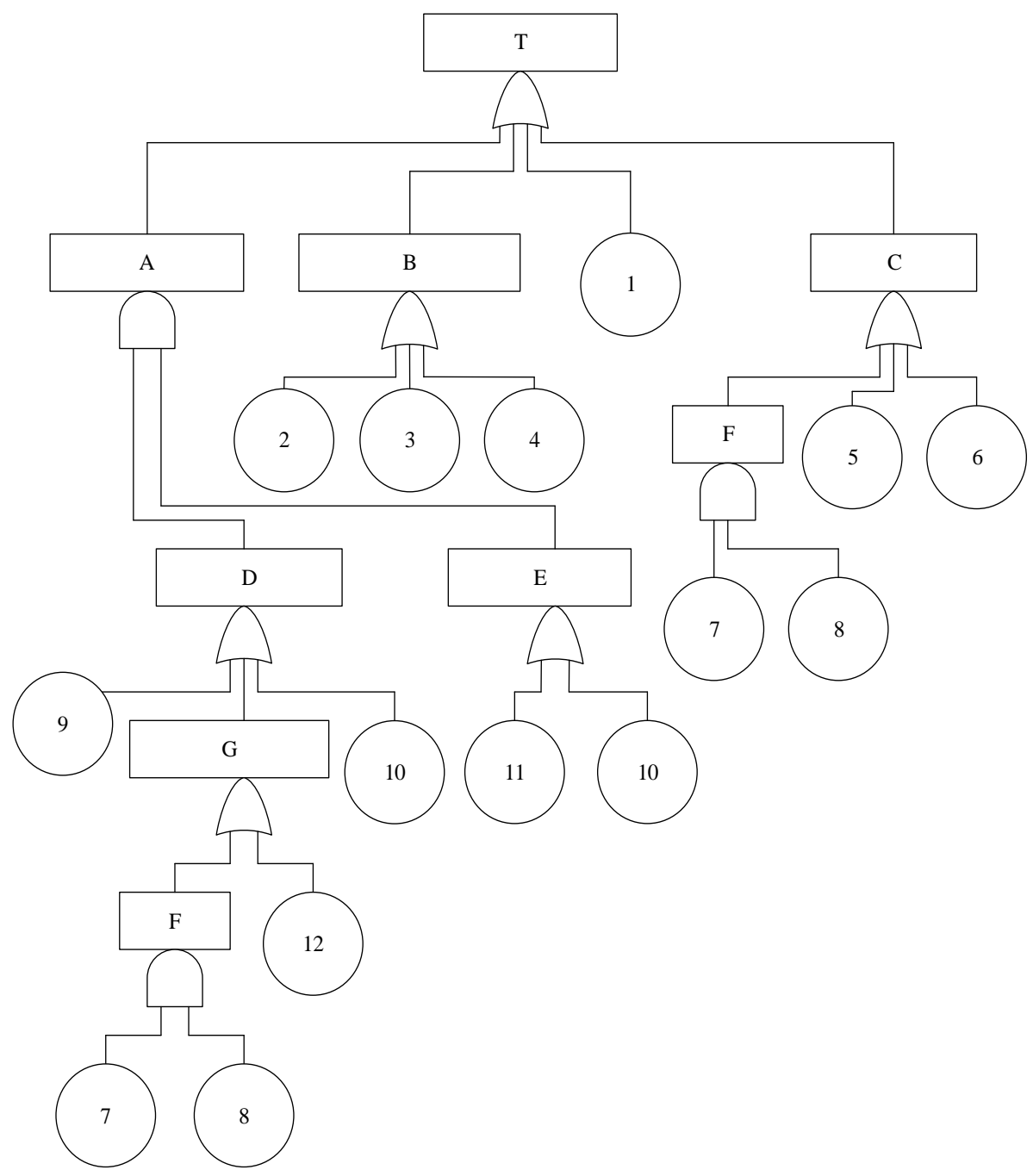

Fig. 1 Fault tree of a fire suppression system for qualitative analysis [5] 
Figure 2 shows the creation of cut sets using a matrix procedure for one part of a sprinkler system fault tree.
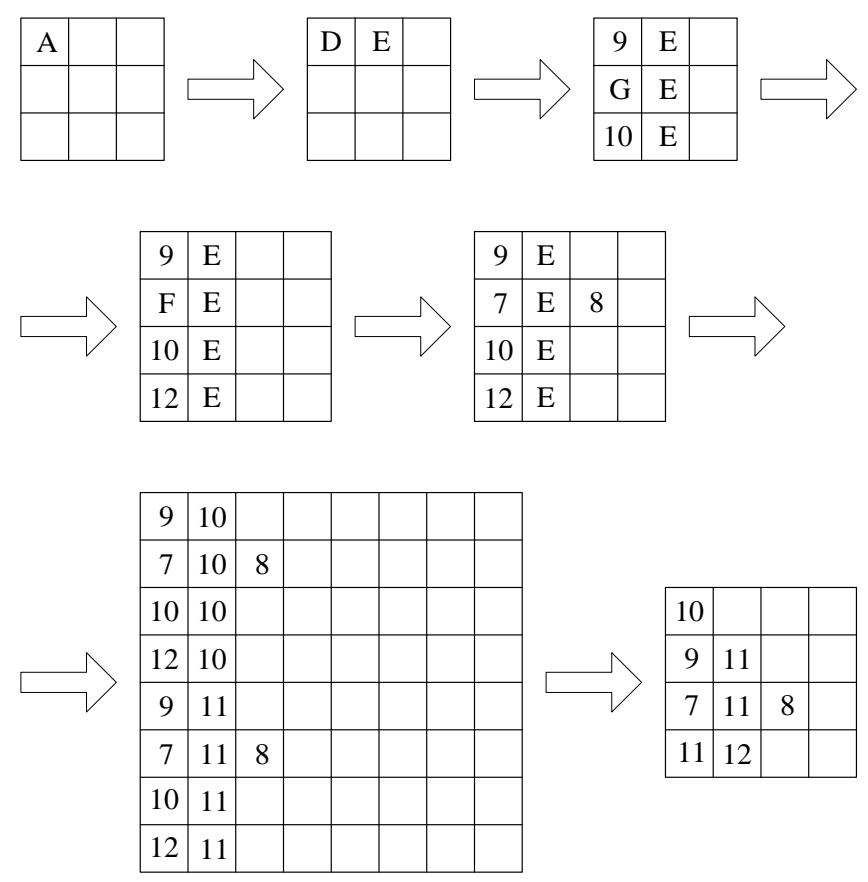

Fig. 2 Creation of minimal cut sets using a matrix procedure [5]

Creation of a minimal cut set using Boolean algebra

$$
\begin{gathered}
T=A+B+1+C \\
A=D \cdot E \\
B=2+3+4 \\
C=F+5+6 \\
D=9+G+10 \\
E=10+11+10=10+11 \\
F=7 \cdot 8 \\
G=F+12=7 \cdot 8+12 \\
D=9+7 \cdot 8+12+10 \\
C=7 \cdot 8+5+6 \\
A=(9+7 \cdot 8+12+10) \cdot(10+11)
\end{gathered}
$$




$$
\begin{gathered}
A=9 \cdot 10+7 \cdot 8 \cdot 10+12 \cdot 10+10+9 \cdot 11+7 \cdot 8 \cdot 11+12 \cdot 11+10 \cdot 11 \\
A=10 \cdot(9+7 \cdot 8+12+1+11)+9 \cdot 11+7 \cdot 8 \cdot 11+12 \cdot 11 \\
A=10+9 \cdot 11+7 \cdot 8 \cdot 11+12 \cdot 11 \\
T=10+9 \cdot 11+7 \cdot 8 \cdot 11+12 \cdot 11+2+3+4+1+7 \cdot 8+5+6 \\
T=10+9 \cdot 11+12 \cdot 11+2+3+4+1+7 \cdot 8 \cdot(11+1)+5+6 \\
T=10+9 \cdot 11+12 \cdot 11+2+3+4+1+7 \cdot 8+5+6 \\
T=1+2+3+4+5+6+40+7 \cdot 8+9 \cdot 11+12 \cdot 11
\end{gathered}
$$

Analytical determination of minimal path sets for a fire suppression system is provided below.

$$
\begin{gathered}
T=A \cdot B \cdot 1 \cdot C \\
A=D+E \\
B=2 \cdot 3 \cdot 4 \\
C=F \cdot 5 \cdot 6 \\
D=9 \cdot G \cdot 10 \\
E=10 \cdot 11 \cdot 10=10 \cdot 11 \\
F=7+8 \\
C=(7+8) \cdot 12=7 \cdot 12+8 \cdot 12 \\
C=(7+8) \cdot 5 \cdot 6=5 \cdot 6 \cdot 7+5 \cdot 6 \cdot 8 \\
A=9 \cdot 10 \cdot 7 \cdot 12+9 \cdot 10 \cdot 8 \cdot 12+10 \cdot 11 \\
T=(9 \cdot 10 \cdot 7 \cdot 12+9 \cdot 10 \cdot 8 \cdot 12+10 \cdot 11) \cdot 2 \cdot 3 \cdot 4 \cdot 1 \cdot(5 \cdot 6 \cdot 7+5 \cdot 6 \cdot 8) \\
T=(1 \cdot 2 \cdot 3 \cdot 4 \cdot 5 \cdot 6 \cdot 7+1 \cdot 2 \cdot 3 \cdot 4 \cdot 5 \cdot 6 \cdot 8) \cdot(7 \cdot 9 \cdot 10 \cdot 12+8 \cdot 9 \cdot 10 \cdot 12+10 \cdot 11) \\
T=1 \cdot 2 \cdot 3 \cdot 4 \cdot 5 \cdot 6 \cdot 7 \cdot 7 \cdot 9 \cdot 10 \cdot 12+1 \cdot 2 \cdot 3 \cdot 4 \cdot 5 \cdot 6 \cdot 7 \cdot 8 \cdot 9 \cdot 10 \cdot 12+ \\
+1 \cdot 2 \cdot 3 \cdot 4 \cdot 5 \cdot 6 \cdot 7 \cdot 10 \cdot 11+1 \cdot 2 \cdot 3 \cdot 4 \cdot 5 \cdot 6 \cdot 7 \cdot 8 \cdot 9 \cdot 10 \cdot 12+
\end{gathered}
$$

$+1 \cdot 2 \cdot 3 \cdot 4 \cdot 5 \cdot 6 \cdot 7 \cdot 8 \cdot 9 \cdot 10 \cdot 12+1 \cdot 2 \cdot 3 \cdot 4 \cdot 5 \cdot 6 \cdot 8 \cdot 9 \cdot 10 \cdot 12+1 \cdot 2 \cdot 3 \cdot 4 \cdot 5 \cdot 6 \cdot 8 \cdot 10 \cdot 11$ 
Figure 3 shows the reliability network for a fire suppression system created based on the fault tree of a fire suppression system.

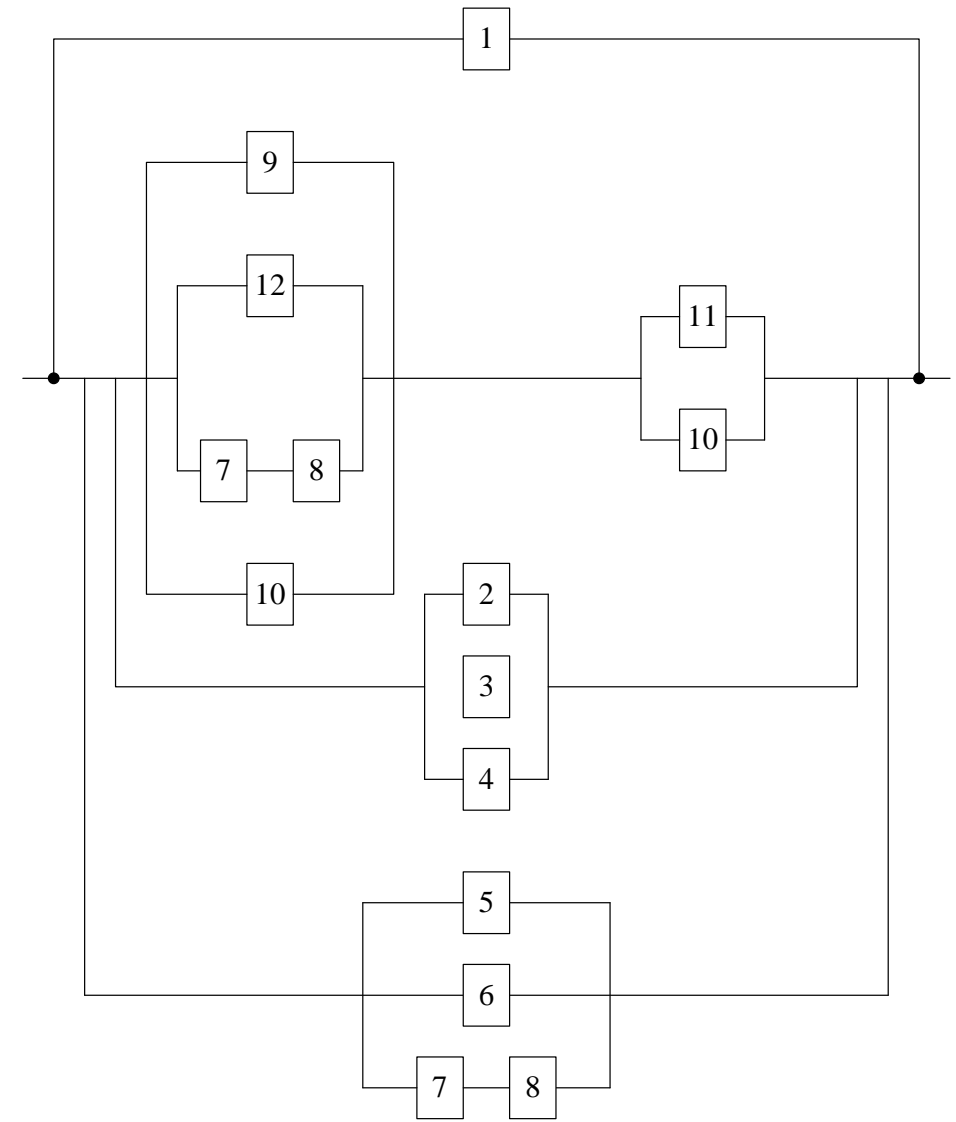

Fig. 3 Fire suppression system reliability network diagram

\section{CONCLUSION}

The paper presented a qualitative analysis of a fault tree of a fire detection and alarm system using minimal cut sets and minimal path sets. Creation of a minimal cut set using Boolean algebra revealed that the failure of specific system components, or individual system events, can lead to the overall system failure and that some events are the greatest contributors to overall system failure.

Creation of a minimal cut set using Boolean algebra revealed that the failure of specific system elements, i.e. specific individual events (sprinkler failure, pipeline failure, main isolation valve failure, panel software failure, panel hardware failure, water supply isolated), can lead to system failure. 


\section{REFERENCES}

1. Blagojević, M. (2015), Alarm Systems (in Serbian), University of Niš, Faculty of Occupational Safety, Niš, Serbia

2. Clemens, L. P. (1993). Fault Tree Analysis (4th Edition). Retrieved from http://www.fault-tree.net/papers/ clemens-fta-tutorial.pdf

3. Hoyland, A. and Rausand, M. 1994. System reliability theory, Wiley, New York

4. Ristić, D., Blagojević, M., Stojiljković, E., 2017., Use of fault tree for assessing fire suppression system reliability, Осма научна конференцир с международно уастие „Гражданската безопасност 2017“, pp. 21-28, Sofia, Bulgaria

5. Ristić, D., Blagojević, M., Krstić, I., Krstić, D., 2011., Fault tree of fire safety systems, Sbornik prednašek XX. Ročniku mezinarodni konference "Požarni ochrana 2011", pp. 305-307, Ostrava, Czech Republic

6. Savić, S., Grozdanović, M., Stojiljković, E. (2014). "System Reliability and Safety" (in Serbian), University of Niš, Faculty of Occupational Safety, Niš, Serbia

\section{ANALIZA POUZDANOSTI SISTEMA ZA GAŠENJE POŽARA}

Metode stabla otkaza i stabla dogažaja su dobro poznate metode za analizu pouzdanosti tehničkih sistema. Međutim, ove metode su retko primenjivanje za analizu pouzdanosti sistema za zaštitu od požara, odnosno sistema za dojavu požara i sistema za gašenje požara.

Cilj ovog rada je da se pomoću hipotetičkih vrednosti verovatnoće događaja, dobijenih kvalitativnom analizom stabla otkaza, dobiju rezultati koji bi ukazali koji pojedinačni događaji dovode do otkaza sistema za gašenje požara, i koji su događaji najznačajniji ili najviše doprinose otkazu sistemau za gašenje požara.

Ključne reči: pouzdanost, zaštita, analiza stabla otkaza, sistem za zaštitu od požara, sistem za gašenje požara, standardi 